\title{
Reversing Nigeria’s Food Import Dependency - Agricultural Transformation
}

\section{Onwuka, Ifeanyi Onuka}

Department of Accounting \& Finance, Godfrey Okoye University, Enugu State, Nigeria

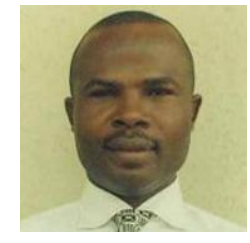

(A) Check for updates

\begin{abstract}
Nigeria currently imports foods for domestic consumption of her citizens. This is puzzling because a greater percentage of her population is engaged in agriculture. This is despite the apparent neglect of agriculture since crude oil was discovered in commercial quantities in the early 1970 s. Before the discovery of oil in exportable quantities, the country depended largely for her foreign exchange earnings on agricultural exports and the various regions in the country were quite active in agricultural production. The Northern region was noted for the groundnut pyramids that dotted the various parts of the region; the Western region for cocoa and the Eastern region were renowned for palm plantations. This success story was not sustained with the discovery of oil, as agriculture was abandoned and neglected by successive governments in the country. However, the decline in crude oil revenue since 2014 has once again exposed the vulnerability of Nigeria's dependence on crude oil as a major earner of foreign exchange. Consequently, Nigeria is finding it difficult to pay for its food import bills and there is hunger in the land. Using exploratory technique with anecdotal evidence, this study highlighted the dangers of relegating agriculture in Nigeria and placed analytical spotlight on agricultural transformation as a solution for reversing the country's food import dependency.
\end{abstract}

Keywords: Food dependency, Agricultural transformation, Net importer, Agricultural products.

\section{Introduction}

Nigeria currently imports various quantities and varieties of foods to feed her teeming population. This is very puzzling considering her huge agricultural potential.

With over 84 million hectares of arable land, of which only $40 \%$ is cultivated; a population of over 170 million people, making her Africa's largest market; 230 billion cubic meters of water; and abundant and reliable rainfall in over two third of its territory, the country has some of the richest natural resources for agricultural production in the world. Indeed, Nigeria was once upon a time a major player in the global agricultural market in the past, as the world's largest producer of groundnuts and palm oil in the 1960s, and the second largest exporter of cocoa. The country was also self-sufficient in food production before the discovery of oil in the 1960s [1].

Since 2010, Nigeria's agriculture sector has witnessed major reforms and transformation. The introduction of Agricultural Transformation Agenda (ATA) by the then administration of President Goodluck Jonathan brought about reforms in the input delivery or Growth Enhancement Support (GES) Scheme, agricultural financing, value chain development, including the Staple Crop Processing Zones, and farm mechanization yielded an abundant harvest for farmers and great gains for the country [2].

Between 2011 and 2014, the country's food production grew by 21 million Metric Tonnes and led to a huge decrease in food imports.

Nigeria's expenditure on food importation fell from an all-time high of N3.19 trillion in 2011 to N635 billion in 2013; a 403\% reduction. Opportunities in farming rose by 3.56 million in the period 2012 to 2014 due to ATA interventions. Agriculture became an exciting sector in Nigeria [3].

These achievements were, however, not sustained in subsequent years. Increase in population, Population growth, low and stagnating agricultural productivity, policy distortions, weak institutions and poor infrastructure have conspired to put Nigeria's once thriving sector in quandary.

Not only is the country depending largely food importation, the country is also finding it difficult to cover her huge food imports bills, owing to downswings in revenues from oil that the country depends on Uma [4]. For the periods 1980 and 2015, Nigeria's aggregate spending on food importation grew at 3.4 percent annually. However, this growth was mostly propelled by population growth (2.6 percent per year); the increase in per capita food import was only about 0.8 percent per year. Food consumption on per capita basis grew only at about 1 percent per year, while food production grew at an even smaller rate of less than 0.1 percent per year. 
The stagnation in consumption and the contribution of imports as percentage of per capita income is in line with the sluggish economy and the eating habits in Nigeria [5]. The contribution of food importation to the GDP in Nigeria is relatively high and represents more than a quarter of percent of per capita income (GDP per capita). As a result, the contribution of food importation to economic growth is also high implying that domestic production has largely lagged behind consumption.

Indeed, local food production has remained relatively low and increased only by 2.7 percent annually, a little above the growth in population. This means that growth in consumption must be compensated by growth in food imports [6]. The sluggish growth in local food production is caused by several factors especially those that relate to agrarian production.

Extant literature shows that local food production in Nigeria has been constrained by technical factors, lack of infrastructure and institutional dynamics in Nigeria [7].

According to a survey by "Save the Children", an international Non-Government Organization (NGO) in December, 2011, majority of parents in Nigeria (68 percent) said that their children complain of hunger. A large percentage of the population in Nigerians have for decades struggled with the challenge of food insecurity [8].

For the periods before the discovery of oil, the country was not importing food but rather was exporting various quantities of foods to other countries especially neighboring countries in Sub-Saharan Africa. All these changed with the discovery of oil and the neglect of agriculture starting from the 1970s. Massive influx of the petro-dollar became a disincentive for investment in large scale, commercialized farming which before then was the country's economic mainstay [9].

Nigeria is ranked $11^{\text {th }}$ globally in arable land but ranked $116^{\text {th }}$ out of 138 farming nations owing to over dependence on fossil fuel and rising revenue from the country's petroleum sector. Today, the country is unable to keep pace with the patterns of its domestic food demand due to neglect of agriculture.

Nigeria continues to import stable food for her growing population [10]. In 2011, the country imported about 3 MMT of rice valued at N468billion (about 20 percent of Sub-Saharan Africa's total rice imports); and over N60obillion of wheat to the detriment of its domestic agricultural development.

Nigeria today is ranked as global second largest importer of rice after the Philippines [11]. But a greater percentage of Nigeria's working population still depends on agriculture, albeit, on low scale, which contributes about 40 percent of GDP and 60 percent of exports other than fossil fuel. Before now, the country was leading in exporting of cocoa, groundnuts, cotton, palm oil, palm kernel and rubber.

In recent times, both the volume and the range of exports commodities have reduced sharply. Today, Nigeria no longer produces sufficient food for the country's large and exploding population. Import dependency has crept in and a large chunk of the country's foreign exchange earnings is leaving the country's coffers daily for this purpose.

It is clear from the foregoing that Nigeria needs an agricultural revolution - a transformation in the agrarian sector in order to decouple the country's food needs on importation. To argue this point more forcefully, the paper develops as follows: section 2 focuses on the causes of the neglect of agriculture and the descend of the country from exporting food in the early 1970s to importing food for nearly four decades starting from 1980s and early 1990s.

Section 3 dwelt on efforts by Nigeria to improve local production in the country. Section 4 focused on constraints to Nigeria's agricultural growth and development while Section 5 reviews options for harnessing Nigeria's agricultural export potentials. Section 6 summarizes the study with policy implication for further developing agriculture in Nigeria.

The methodology adopted is largely descriptive and analytical with anecdotal evidences where necessary.

Section 2 - Causes of Decline in Local Production in Nigeria

From early 1980s, when prices of cash crops especially oil, coffee, cocoa and spices, plummeted, Nigeria could no longer produce enough for export but was rather importing food. This affected the country's foreign exchange earning capacity [12].

Since 1980, importation for food and allied products have continue to grow at faster rate than exports and reached its peak in 2007 when a whopping sum of USD 47 billion was spent on agricultural imports [13, 14] yielding a deficit of about USD 22 billion.

As observed by Uma [4] increase in population, low productivity, discontinuities in policy, weak institutions and inadequate infrastructure have been blamed for Nigeria's dismal performance in agricultural production. These factors require elucidation.

\section{Population Size, Structure and Growth}

Since early 1980s, Nigeria has posted the most population growth rate in the Sub-Saharan region, which suggests that Nigeria's growing population is one of the contributory factors for food import increase. In 2011, Nigeria's posted a population growth rate of 2.34 percent, which was nearly the double of the Africa continent average population growth rate of 1.65 percent [15].

The population structure in Nigeria shows that about a quarter of the country's population is under the age of 15. Nigeria's young and growing population poses a threat to food security, implying that in areas where local production is low, food must to be imported to satisfy demand [16].

Given that the growing population size has led to increase in imports, it is important to know whether the population growth per se or the growth in net food imports (or consumption) per capita caused the import rise. Data indicate that for the periods 1980 and 2015 the aggregate food imports (in real term, i.e. deflated) for Nigeria grew at about 3.4 percent per year while population grew at about 2.6 percent annually [17]. This implied, ipso facto, increase in population has been the major contributor factor food import growth and that per capita food imports grew only at 0.8 percent annually. 
This shows that although per capita net imports of food have been on an upward trend, the trend tended to have fluctuated betweenUSD8 and USD 15 per capita between the periods of 1980 s and 2011. The deflated value of per capita food imports show a similar but clearer pattern, with net imports stabilizing around USD10-18 during that period [13].

Such a stagnation of per capita food importation contrasts the steady and sharp rise in aggregate food imports since the 1980'sand confirms that population increase contributed to the increase in Nigeria's import demand for food since the turn of the century.

\subsection{Low Yields in Agriculture}

In the extant literature, yield is neither a complete nor a perfect measure of total productivity, but it provides a broad insight into how Nigeria's levels and increase of agricultural productivity, hence production, lag far behind countries in Europe, the United States, Asia and even for peer countries in Sub-Saharan Africa especially for main food staples such as rice, cereals, vegetable oils, dairies, and meat.

For instance, for the periods 1980 to 2014, world maize yields doubled from 2.5 to more than 5 tons per hectare, while Nigeria's production stayed at less than2 tons per hectare [18]. Similarly, during the same period, average cow milk production per animal in Nigeria remained below 0.5 tons per animal, that is one-fourth of the world's average [18].

With such low productivity and with the decline in cultivatable land per capita, it is clear why agricultural production grew slower than local demand; this is factor for the rise in importation in Nigeria.

Low agricultural productivity also implies both misallocation of resources and inefficiencies that translate into relatively higher production costs that reduce competitiveness [19]. As low productivity is one of the factors why growth in production (both total and per worker) is weak, it is important to examine why productivity is generally low in Nigeria.

The technical causes of low productivity in Nigeria can be categorized into three, namely: lack of access to essential inputs and equipment, slow transfer and adoption of technology, and negative supply distortions such as natural disasters and diseases.

\subsection{Lack of Access to Essential Inputs and Equipment}

Land degradation has been a major constraint on agricultural (crop and livestock) production in Nigeria.

Crop and grazing lands have been continuously depleted of soil nutrients, and any extension of agricultural activities on new land holds only short-lived benefit, because there is hardly any restoration of the soil quality [20].

Moreover, Nigeria experience soil erosion, and conservation techniques are often neglected. These have negative impacts on yields and productivity.

\subsubsection{Low Fertilizer Uses and Difficulty of Control of Pests and Diseases}

One way to curb land degradation is to use fertilizer, but in Nigeria the use of fertilizer in agricultural production is low compared with the level of use globally.

In 2010, the average amount of fertilizer used per hectare in Nigeria was only about $11 \mathrm{~kg}$, which was less than one-tenth of global average [16]. The low level of fertilizer use stems from the relatively high prices and inefficient delivery systems.

Moreover, despite Nigeria's agro-climatic conditions that make its agricultural sector susceptible to animal and plant diseases, the use of pest controls and animal vaccines is still limited.

\subsubsection{Water Constraint}

Water for food production (including livestock) is threatened by other water uses (e.g. energy for industries and urban centres, or for non food production).

Regional wars often arise because of competition over water use.

Moreover, even available water sources for agriculture often cannot reach the users because of the lack of infrastructure. In the northern parts of the country frequently hit by drought, water stress reduces yields especially for production under an extensive farming system [20].

Data from FAO/UNIDO [21] showed that the proportion of irrigated land to total crop land in Nigeria is relatively small, indicating that Nigeria's food commodities and livestock are highly susceptible to prolonged droughts.

\subsubsection{Low Mechanization, Poor Infrastructure and Inadequate Equipment}

Animal traction and engines supply 75 percent of power needs in agriculture in other developing regions such as Asia and Latin America, while in Nigeria they represent only 35 percent of agricultural power source; the remaining 65 percent comes from human muscle [21].

Data from FAO/UNIDO [21] compared the number of tractors used per 100 sq.km of arable land and confirms the low level of mechanization of Nigerian agriculture. The high and fluctuating costs of energy and the high price of equipment are contributory factors for the limited use of motorized agricultural equipment by farmers in Nigeria.

Similarly, the use of large equipment such as tractors is not suited for use in most areas in Nigeria because food production is on small and scattered lands. Moreover the level of mechanization is often associated with irrigation systems, as irrigated land accommodates mechanization, whereas dry land is less amenable.

Many areas in Nigeria still lack basic agricultural infrastructure such as irrigation dams, storage facilities and cold chains and modern slaughter houses and this state of infrastructure limits productivity and production. Similarly the lack of basic equipment affects not only the quantity but also the quality of products. 
In the northern regions of Nigeria the lack of appropriate and sanitized equipment in slaughter houses and the absence of cold chain in the dairy sector have reduced the quality of meat and milk circulating in the market.

\section{Limited Access and Adoption of Technology}

The available technology does not always reach most farmers in Nigeria. One reason is the high costs associated with technology transfer and adoption. Animal vaccines or improved seeds are luxuries for a large number of farmers in Nigeria.

Another common obstacle to adoption of technology in Nigeria is the lack of human capital and the lack of investment in agricultural research and extension [22-24]. Poor human resources can be seen through low secondary school enrolment, especially in the northern region of Nigeria.

Moreover, as Von Cramon-Taubadel, et al. [24] shows, Nigeria's government investment for agricultural research is small compared to agricultural output.

This is considered abysmal even for peer countries in Africa like Botswana and South Africa where investment for agricultural research is over 15 percent of agricultural output. For many years, Nigeria's policy makers have not given enough attention and resources to capacity development in areas of agriculture and food production sectors.

Indeed, Nigeria lacked an effective extension program to expand the utilization of technology, even sometimes the rudimentary forms. Undoubtedly, absence of clear policies to speed up access and adoption of technology is one of the sources of the lack of productivity growth in Nigeria.

The slow pace of technology adoption is also reflected in the types of farming system and the high seasonality of the country's food production.

Although a move towards more intensive production systems as seen primarily in the proliferation of periurban agriculture, Nigeria's agricultural production systems remain largely extensive, especially for food crops and livestock production [25].

The contribution of modern agriculture to food sufficiency in Nigeria has increased in recent times but it still remains generally limited.

In livestock production, for instance, pastoralism is still the dominant livestock production system in Nigeria despite the upsurge in animal rearing near cities [26].

As remarked by Maitima, et al. [26] whereas an extensive farming system offers some advantages such as limited pollution, organic purity of the crop or livestock products, and mobility to reach needed resources, it can also be an obstacle to productivity growth because of the difficulty of controlling input use that can, for instance, increase the number of growing seasons (i.e., reduce seasonality), and as a result of the difficulty of controlling risks like contagious animal and plant diseases.

Extensive farming systems compound even lower yields and profits as they deplete already scarce resources (fresh water, soil nutrients) of the exploited areas.

\section{Natural Disaster and Diseases}

Natural disasters such as burst dams from neighboring countries, droughts, and flooding spells have affected production by destroying crops and livestock and also by damaging infrastructures.

Climate changes also played a part in these disasters (especially drought or desertification) in some of Nigeria's production areas $[27,28]$. Frequent outbreaks of fire and diseases have destroyed animals and plants (e.g. Avian Influenza for poultry; Rinderpest; foot and mouth diseases).

The lack of prevention and awareness and the poor insurance coverage worsen the impact of natural disasters and animal and crop diseases on the productivity of agricultural sector. Similarly, human diseases such as HIV/AIDS, malaria, and cholera that hinder the productivity of the agricultural workforce, which in effect, also reduce agricultural products in Nigeria as was evidenced in a study in Cape Town by Steinberg, et al. [29].

Human diseases also affect trade balances because, for instance, many importing countries will refuse food shipments for years from countries with disease outbreaks (e.g. cholera or bubonic plague) for health safety reasons [30].

Supply shocks arising from disruptions in the international market such as the oil glut in the early 1970 and global upheavals such as in early 2000 s have affected Nigeria's agricultural production by lowering demand while input and equipment prices and the cost of living in general remain high(stagflation) for rural households.

These shocks have also tightened the already limited financial resources devoted to agro produce and investments in human capital and agricultural research.

\section{Poor Infrastructure, Services and Low Investment}

\subsection{Infrastructure and Services}

Although, on the aggregate, the low level of productivity stands as the main cause of Nigeria's weak domestic supply responses, there are also cases where local produce is high but does not reach consumers as a result of poor infrastructure, mainly roads, within the country.

For instance, a lot of cash crops in Nigeria are cultivated in the northern region of the country but demand is greater in the southern region. Livestock like cattle is also the predominant occupation in the north but with demand in the southern part of the country and the only major means of movement is road which in various areas of the country is in a state of disrepair.

Ndulu and O'Connel [31] observed that Nigeria's merchandize business have been hampered by its remoteness: the country is not well connected and even within the country, cities, towns, and villages are often isolated from one another. This disconnect is mainly due to the lack or degradation of infrastructure, which constitutes a barrier to trade and weakens the supply response to rising food demand. 
This inefficiency is amply demonstrated by the reason that within Nigeria, there are many areas with food production surpluses while other parts suffer from severe shortage. For instance, before 2000, only 17 percent or less of all roads in Nigeria are properly paved.

Degraded rural roads, insufficient and ill-equipped harbors and deficient transportation equipment in Nigeria have increased production and marketing costs that make local food products uncompetitive for local and international markets.

Most farmers in Nigeria are often forced to sell at low prices to the nearest buyers or be faced with the chance of losing their entire harvests, while food exporters struggle with poor storage facilities and many days of delay at ports. As rural infrastructures are degraded and entry to local markets remains difficult for farmers, wholesalers (collectors) and transporters often make wide marketing profit to the detriment of local farmers.

Agricultural markets, where they even exist in Nigeria, have been dominated by few buyers where an increase in retail price (due for example to the reduction of price distortions) may not benefit producers. In this case, any increase in price will likely be retained by agents elsewhere in the marketing chain (middlemen, manufacturers, wholesalers or retailers).

Food producers are often price takers, and when they perceive no benefit from a price increase, their incentive to increase production declines further.

\subsection{Lack of Investment in Food Production}

Besides the resources to build infrastructure, lack of investment (financial and physical capital) has weakened local agricultural production in developing countries, including those in Africa [3].

Estimates of the scope and increase of public and private agricultural investments in Africa have been low in comparison with global standards [32].

Currently, there is reawakening on agricultural investment from rich but agricultural resource-constrained countries that become are aware of the need to have a secure and stable food supply [24].

While the economy-wide implications of foreign agriculture investment remain subject to debate, it is generally agreed that the lack of investment in agriculture has prevented food growers from accessing essential inputs and equipment, and thus hampered food output growth.

\section{Institutional Deficiencies, Insecurity and Conflicts}

The courses of post-independence politics in Africa have been erratic and marked by numerous internal and even regional conflicts.

These problems often arise because of rivalries for the control of resources (land, water, forest, minerals, and oils); the 'curse' of resource-rich countries, as some authors [33] called it, seems to hover over many parts of the continent and make these locations unstable and unsafe. These conflicts have affected productivity and production because the labour force has been displaced and the already weak input delivery and output distribution are brought to their knees.

Worse, some infrastructure (roads, ports) required for agricultural production and distribution may be hampered.

Likewise, during wars, livestock movement is limited or confined to areas where grassland is scarce. By implication if regional and internal conflicts are resolved, an increase in production and productivity could emerge, as is the case in the once war-torn countries of Mozambique, Rwanda, and Uganda.

Institutional deficiencies, insecurity and conflicts in most African countries affect not only food production but also consumers' preference and choice as well.

On the production side, Fulginiti, et al. [34] show that, in Sub-Saharan Africa's colonial heritage, lack of political freedom, conflicts, and war have had significant impact on agricultural production and productivity.

On the demand side, the absence or weakness of structures that protect consumers' rights and control the safety and quality of food circulated in the market in many African countries, including the richer ones, is widely known $[30,35,36]$. This has encouraged entry of cheaper foreign products whose sanitary quality are sometimes suspect (i.e., the dumping of expired or nearly expired products).

These problems have certainly contributed to the food-trade deficit in many African countries. As an example of the lack of institutions, marketing boards that bore some of the roles of market institutions have been abolished (often for good reasons), but there has been no replacement to fill in as an entity for trade and market surveillance.

Chambers of Commerce and Industry in Nigeria like in many African countries often limit their activities to issues concerning large-scale farming, whose influence on the setting agenda far exceeds that of small-scale farming. Additionally, insurance markets for crops or livestock have remained difficult to implement and expand. Moreover, Nigeria like most African countries, with the exception of a few countries (such as Ethiopia, Kenya, and South Africa), do not have an operating platform for commodity exchanges. These institutional deficiencies have reduced the effectiveness of policy reforms and efforts to raise production and productivity.

Fafchamps and Minten [37] conclude that insecurity affects rural welfare in some African countries. Instability and insecurity disrupt input delivery and output distribution and create uncertainties that reduce incentives to invest in and adopt new technology.

Similarly, conflicts and especially wars displace workforce and livestock and disrupt production processes and productivity.

The disruption of input deliveries and displacement or migration of workforce or livestock are abrupt and, in many cases, irreversible.

Conflicts and wars also destroy the already degraded infrastructure, worsen food production and food distribution, and increase the dependency on food donations and imports. Insecurity and instability are among the problems that have turned away both local and foreign investors. 
The consequences of the insecurity that starts in one country may easily spread to neighboring countries, leading to regional crisis affecting most agricultural producers in the region. Theft of crops and live animals is widespread in many parts of rural Africa and it dampens expectations and motivation of farmers.

\section{Section 3 - Efforts by Government to Boost Agricultural Production in Nigeria}

Nigeria's attempts to boost domestic agricultural production have not always been successful. For instance, in 2003, the government launched a robust program to raise local rice production to 6 million metric tonnes by the end of 2007.

However, the program could not achieve the target, a failure attributed to frequent changes in agricultural policies. The dependence on imported foods has hampered the productive level of the local farmers; displacing local production and creating rising unemployment.

Nigeria's food imports now grow at an unsustainable rate of about 11 percent annually [21]. Generally, any country that seeks to reverse dependence of her citizens on importation, usually face two different pathways. One way to go is to reduce directly the agricultural (including food) trade deficit by finding ways to reduce agricultural imports and boost local production and agricultural exports. Methods such as import substitution, export diversification, and protection policies belong to this solution.

The other pathway is to temporarily ignore the agricultural trade imbalance and to find ways to increase exports in non-food or non-agriculture sectors (services, tourism, oil and mining, etc.) to finance food bills. Debates rage on which one of the two pathways is optimal and sustainable for each country, but the two are not mutually exclusive.

For instance, providing basic infrastructure (such as roads, ports, and laboratories) can benefit both agricultural and non-agricultural exports whether or not targeting a balanced agricultural trade is the priority. Similarly, development of tourism and other areas that are not agricultural does not preclude but may even enhance efforts to improve productivity and efficiency of local agricultural production to supply hotels and restaurants; it may in the end contribute to reducing the agricultural trade deficit.

Hence, for Nigeria where high food import bills are a real burden, the problem is less a matter of choosing a single pathway but more of determining broadly the types of actions that will reduce the burden of persistent and high import bills, given available resources.

Determining which actions can reduce importation and ensure food security requires a full investigation of the causes of the persistent and rising net agricultural and food imports. However, recent efforts by Nigerian authorities to improve domestic agricultural production deserve some mention.

Starting with the last administration of President Goodluck Jonathan was the Transformation Agenda which draws inspiration from the country's Vision 20:2020 places agriculture as its main pillar. Beyond food sufficiency, the agricultural transformation plan was designed to industrialize the agricultural sector so that it becomes a business that can create jobs, export earnings and prosperity [8].

Some of the basic objectives of the initiative are to significantly reduce food imports especially rice and wheat, to add 20 million metric tonnes of food to domestic supply; boost export earnings from agricultural produce and create 3.5 million jobs in the sector.

The Transformation Agenda envisaged a Gross Domestic Product (GDP) growth rate of 11.7 percent translating to N426.6billion and N73.2 trillion for real and nominal GDP respectively; and in all of this, agriculture was projected to play a pivotal role [38].

Similarly, the National Economic Management Team set up the then President Goodluck had also identified and selected agriculture as its main beacon for employment generation and poverty reduction and had accordingly through the Federal Ministry of Agriculture and Rural Development articulated a programme for implementation called the Agriculture Transformation Agenda (ATA).

Through this initiative, agriculture was expected to contribute to about 36 percent of the expected GDP growth rate going forward. Consequently, budgets 2013-2015 were expected to reflect this growing importance placed on agricultural development.

According to the Transformation Agenda, policies and objectives for developing the agriculture sector include:

- Secure food and feed needs of the nation

- Enhance generation of national and social wealth through greater export and import substitution

- Enhance capacity for value addition leading to industrialization and employment opportunity

- Efficient exploitation and utilization of available agricultural resources

- Enhance development and dissemination of appropriate and efficient technology for rapid adoption

- Self sufficiency in rice production

- Self sufficiency in fertilizer production

The policies were built on development programmes in the sector such as Special Program for Food Security, FADAMA II Program, Fertilizer Revolving Fund, Presidential Initiative on Cassava, Rice, Vegetable Oil, Tree Crops and Livestock, as well as many other existing initiatives [39].

Worthy of note was that the new Transformation Agenda was designed to leverage on existing agricultural policies in the spirit of continuity in government programmes.

As part of the agricultural reforms, the government had increased both the levy and duty on wheat and rice, effective July $1^{\text {st }} 2012$ and imposed a 100 percent import duty on wheat flour; 20 percent on wheat grain, 30 percent on husked brown rice and 50 percent on polished rice.

Other fiscal policy measures implemented at various times during the year 2012 include zero duty on agricultural machinery and equipment; zero duty on power sector equipment and machinery; prohibition of cassava flour importation and zero duty on cassava flour processing equipment [39]. The present government of Mohammadu Buhari has also unleashed efforts to tackle food insufficiency in the country. 
Under the Federal Ministry of Agriculture and Rural Development, the government released an Agriculture Promotion Policy $(2016$-2020) which was expected to anchor on the successes of the Agricultural Transformation Agenda (ATA) of the last administration; closing key gaps in policy and strategy document.

According to the Agriculture Promotion Policy [39] Nigeria is facing two key gaps in agriculture: an inability to meet domestic food requirements and an inability to export at quality levels required for market success.

The earlier issue is a productivity challenge driven by an input system and farming model that is largely inefficient. As a result, an aging population of farmers does not have enough seeds, fertilizers, irrigation, crop protection and related support to be successful.

The latter challenge is driven by an equally inefficient system for setting and enforcing food quality standards, as well as poor knowledge of target markets.

Lack of testing facilities, a weak inspectorate system in Federal Ministry of Agriculture \& Water Resources, and poor coordination among relevant federal agencies serve to compound early stage problems such as poor knowledge of permissible contaminant levels.

According to the Agriculture Promotion Policy, putting Nigeria's agriculture sector on a path to growth will require actions to solve these two gaps: produce enough fresh, high quality foods for the Nigerian market; and serve the export market successfully and earn foreign exchange.

The new federal Agricultural Promotion Policy (APP) is a framework that focuses on tackling the basic problem at the heart of limited food production and delivery of quality standards. As productivity improves domestically and standards are raised for all Nigerian food production, export markets will also benefit impacting positively on Nigeria's balance of payments.

Given the limited resources and the need to deliver sustainable results, the Federal Ministry of Agriculture \& Rural Development (FMARD) in consultation with partners identified an initial pool of crops and related activities that will be Nigeria's path to tackling the aforementioned gaps.

First, FMARD prioritized improving productivity into a number of domestically focused crops and activities. These are rice, wheat, maize, fish (aquaculture), dairy milk, soya beans, poultry, horticulture (fruits and vegetables), and sugar.

Nigeria believes that the gap can be closed by partnering closely with private investors across farmer groups and companies to develop end to end value chain solutions. These areas are expected to receive robust government assistance.

Second, FMARD prioritized for export markets the production of the following crops and activities: cowpeas, cocoa, cashew, cassava (starch, chips and ethanol), ginger, sesame, oil palm, yams, horticulture (fruits and vegetables), beef and cotton.

FMARD is expected to collaborate with core investors to promote infrastructure development in agriculture. The aim is to ensure that Nigeria develop a quality brand for local consumption and for export.

Finally, FMARD will periodically publish metrics to track performance against the strategy e.g. tonnage of rice paddy produced, or yields/milking cow. The system was to repeatedly collect accurate data and integrate these into policy making, as well as investor planning.

It was expected that if successful, key gaps such as Nigeria's continued imports of rice will disappear, while Nigerian produce e.g. beans and cocoa will once again become a quality benchmark across the globe. Reaching that point will require significant investments in people, processes and systems.

In recent times, the most ambitious approach to improving agricultural production in Nigeria is the Anchor Borrowers Program (ABP) launched by the Federal Government of Nigeria on 17November, 2015 by the present Government of MohammaduBuhari.

The program was launched under the auspices of the Central Bank of Nigeria (CBN). As part of its developmental function, the CBN established the Anchor Borrowers' Program (ABP). The Program is intended to create a linkage between anchor companies involved in the processing and small holder farmers (SHFs) of the required key agricultural commodities.

The programme thrust of the ABP is provision of farm inputs in kind and cash (for farm labour) to small holder farmers to boost production of these commodities, stabilize inputs supply to agro processors and address the country's negative balance of payments on food.

At harvest, the SHF supply his/her produce to the Agro-processor- the Anchor who pays the cash equivalent to the farmer's account.

The Programme evolved from the consultations with stakeholders comprising Federal Ministry of Agriculture \& Rural Development, State Governors, millers of agricultural produce, and smallholder farmers to boost agricultural production and non-oil exports in the face of unpredictable crude oil prices and its resultant effect on the revenue profile of Nigeria.

The key objective of the ABP is to create economic linkage between smallholder farmers and reputable largescale processors with a view to increasing agricultural output and significantly improving capacity utilization of processors.

Other objectives include:

- Increase banks' financing to the agricultural sector

- Reduce agricultural commodity importation and conserve external reserves

- Increase capacity utilization of agricultural firms

- Create new generation of farmers/entrepreneurs and employment

- Deepen the cashless policy and financial inclusion

- Reduce the level of poverty among smallholder farmers

- Assist rural smallholder farmers to grow from subsistence to commercial production levels. 
The loan is targeted at smallholder farmers engaged in the production of identified commodities across the country. The Farmers should be in groups/cooperative(s) of between 5 and 20 for ease of administration. The targeted commodities of comparative advantage to the State shall include but not limited to:

- Cereals (Rice, Maize, wheat etc.)

- Cotton

- Roots and Tubers (Cassava, Potatoes, Yam, Ginger etc.)

- Sugarcane

- $\quad$ Tree crops (Oil palm, Cocoa, Rubber etc.)

- Legumes (Soybean, Sesame seed, Cowpea etc.)

- Tomato

- Livestock (Fish, Poultry, Ruminants etc.)

- Any other commodity that will be introduced by the CBN from time to time.

The loan is structured to be disbursed through any of these PFIs:

- Deposit Money Banks (DMBs)

- Development Finance Institutions (DFIs)

- Microfinance Banks (MFBs)

The Anchor of the produce from the loan shall be private large-scale integrated processors who have entered into an agreement with the SHFs to off-take the harvested produce at the agreed prices or as may be reviewed by the PMT. State Governments may act as Anchor upon meeting the prescribed conditions.

Other important details about the Anchor Borrowers Programme (ABP) include:

Inputs Suppliers: The input suppliers shall submit expression of interest letter to the office of the PMT for consideration and issuance of local purchase orders

The Loan Amount: The Fund shall be provided from the N220 billion Micro, Small and Medium Enterprises Development Fund (MSMEDF). Loan amount for each SHF shall be agreed upon from the economics of production agreed with stakeholders.

Interest Rate: Interest rate under the ABP shall be guided by the rate on the N220 billion MSMEDF, which is currently at $9 \%$ per annum (all inclusive, pre and post disbursement). The PFIs shall access at $2 \%$ from the CBN and lend at a maximum of $9 \%$ per annum.

Tenor: The tenor of loans under the ABP shall be the gestation period of the identified commodities.

Repayment: Loans granted to the SHFs shall be repaid with the harvested produce that shall be mandatorily delivered to the Anchor at designated collection center in line with the provisions of the Agreement signed. The produce to be delivered must cover the loan principal and interest.

All these efforts demonstrate that Nigeria is committed to taking the necessary steps in order to move Nigerian agriculture from "a business" to a commercial ecosystem that can produce the capabilities necessary to create sustainable jobs and wealth.

The rationale behind these policy moves was to expand domestic production of the staples, which would serve to generate employment, while the extra levy was intended to put further strain on the importation of the commodities and protect the local producers.

While the trade policy reforms were designed to allow for a certain level of protection of the agricultural sector, it nonetheless had to be measured against the World Trade Organization (WTO) and Common External Tariff (CET) arrangements and also the tenets of a consistent, transparent, certain and predictable policy. The theory of comparative advantage by David Ricardo, argues in favour of free trade among countries as long as each country focuses on the activities where it has a relative production advantage [40].

Some economists argue that protection diminish general economic welfare, while others argue in its favour. Critics argue that productivity and growth rates of industrialized economies have been halved during periods of liberalized global commerce, compared with the period when trade was more regulated.

These policy moves may seem protectionist but the government has limited options in the interim to reverse the anomaly.

These protectionist policies were expected to assist government generate savings and increase its revenues from domestic taxes.

The disadvantage is risk of increased smuggling activities as the demand outweighs supply in the interim and the cost of importing these products increases due to the levy hike ultimately affecting supply.

In addition, a porous border and poor monitoring further fueled the import bills of these affected items. At the states and local government levels, several agricultural initiatives were also implemented.

Delta State for example, had in an effort to improve agricultural productivity and promote food availability in the state introduced the Delta State Task Force on Communal Farming (Tfff); Youth Empowerment through Agriculture (Yeta) Program; Farmers Support Program, among others.

Ekiti State has also introduced the Youth Commercial Agriculture Development (YCAD) program aimed at repositioning the state as the food basket of the South-West and creating employment for at least 20,000 youths in the sector. The state had partnered with local banks to provide credit facilities to farmers in order to boost food production and create wealth.

Benue State has also taken steps to improve its agriculture, a sector that has been its traditional economic mainstay earning it the nickname of the "food basket of the nation". Part of the State's initiatives include encouraging the setting up of farmers' cooperatives to enhance easy access to bank loans, agricultural machinery, chemicals and consultancy services from experts.

Aside from the provision of improved seedlings and livestock breeds to farmers, the State Government had also made efforts to open up access roads to rural areas to ease movements of farmers and their produce. The setting up of the Taraku Mills Limited and Agro-millers had helped to ensure that farmers get improved returns on their commodities. 
The state has also set up the Commodity Exchange Board and the Benue Tractor Hiring Agency (BENTHA), all in efforts to boost farming output, alleviate poverty and create more jobs in the sector. On its part, the Kwara State government launched the Kwara Agriculture Master Plan (Policy; KAMP).

The five year plan maps out a phased implementation of a highly productive and sustainable agriculture program with emphasis on increasing output and enhancing the profitability of large, medium and small scale farmers.

The plan was also targeted at improving human and institutional capacity, improving food security and creating job opportunities.

The Central Bank of Nigeria in collaboration with the Federal Ministry of Agriculture has also launched several agricultural development initiatives in recent times, much of which are targeted at providing public sector funding and credit guarantees to diverse categories of farmers.

The apex bank promoted an initiative that encourages commercial banks to increase loans and advances to farmers. Some of such initiatives include the Commercial Agriculture Credit Scheme (CACS) launched in 2009 to provide finance for the country's agricultural value chain (production, processing, storage and marketing).

Others include the Nigeria Incentive-Based Risk Sharing System for Agricultural Lending (NIRSAL) [41].

While these policies and objectives are laudable, their effectiveness will however depend amongst other factors on commitment and political will, resource allocation, implementation and management. These are pertinent concerns given Nigeria's antecedents in the execution of policies and programmes.

The key threats that could hinder the realization of these laudable policy objectives include low agricultural productivity, continued reliance on rudimentary tools and cultural practices, weak linkage to agricultural and industrial sector and inadequate funding.

\section{Section 4 - Constraints to Nigeria's Agricultural Growth and Development}

At the Second Ordinary Assembly of the African Union in Maputo (Mozambique) on $2^{\text {nd }}$ July, 2003, African Heads of State and Government endorsed the "Maputo Declaration on Agriculture and Food Security in Africa" (Assembly/AU/Decl. 7(II).

The Declaration contained several important decisions regarding agriculture, but prominent among them was the "commitment to the allocation of at least 10 percent of national budgetary resources to agriculture and rural development policy implementation within five years". Meanwhile, fourteen years on, just eight countries in the continent, excluding Nigeria have fulfilled this promise.

Although agriculture contribute about 40 percent to the Nigeria's GDP, provides employment and means of livelihood for more than 60 percent of the productively engaged population, the sector received only 3 percent and 1.66 percent of budgetary allocation in 2011 and 2012 respectively.

Also, only about 5 percent of Nigerian farmers have access to modern seeds, while the nation uses 13 kilogram (Kg) of fertilizer per hectare, as against the global average of $100 \mathrm{Kg}$ per hectare or $400 \mathrm{Kg}$ per hectare in China [42]. National farm yield has also dropped to an all time low of one tonne per hectare as against the global average of five tonnes; while the storage system has practically broken down to the chagrin of the toiling farmers and the nation's economy [16].

Only a meager percent of bank loans go to agriculture, yet, this is a sector that employs about 60 percent of the population. Under-funding in this regard is central to the problem of food production and food insecurity in the country [43]. The loss of food sovereignty and dependence on importation makes the country susceptible to fluctuations in the global food market.

For instance, agriculture output grew at its weakest rate in seven years in Q1-2014, increasing by only 4.15 percent year-on-year [18].

The connections among dwindling food production capacity, rising food prices, and dependence on food importation are nowhere more clearly demonstrated in recent times than in the Sahel food crisis, which also affects many of the 11 northern states of Nigeria situated in the Sahel belt.

According to the National Emergencies Management Agency (NEMA) [44] about 30 percent of the population (about 15 million people) in the northern region is food insecure. Other research findings also establish a strong correlation between hunger and the rising trends in poverty in Nigeria [45].

Indeed, poverty and hunger are part of urban problem due largely to the rapidly shrinking employment opportunities and high costs of living.

Compounding the issue is inconsistencies in government's policy formulation and implementation strategies. Another factor contributing to Nigeria's growing dependence on food imports has been the preference among middle-class Nigerians for imported agricultural produce.

For instance, rice from Thailand and India is often perceived to be of superior quality when compared with domestically produced rice.

Though the government applies import levies as a way of countering this problem, preference for, and incidences of high importation of food staples remain $[2]$.

Other hindrances include low productivity, inadequate private sector investment, lack of competitiveness, shortage of skilled manpower, low investment in research and development, poor development of value chain and storage, low value addition, poor regulatory environment, poor quality of agricultural products, decay in physical infrastructure, inconsistency in government policy, poor state of technology, lack of effective and free flow of information.

\section{Section 5 - Options to Harness Nigeria's Agricultural Export Potentials}

For many agricultural producers, prices of their commodities are often times unpredictable and uncertain, resulting in less-than optimal production and investment decisions [46]. According to Fulginiti, et al. [34] the reasons for the wide fluctuation in the agricultural commodities market are obvious. 
First, farm produce varies from period to period, highly dependent on the influences of natural forces such as weather conditions and pests. Second, demand elasticity is relatively small with respect to price; and supply elasticity is low, at least in the short-run. In order to return supply and demand to state of equilibrium, prices have to vary rather strongly, especially if stocks are low.

Third, as result of the long gestation period in agriculture, supply cannot respond much to price changes in the short term, though it can do so much more the production cycle is completed. As a result supply response to price changes can cause cyclical adjustments that add an extra degree of variability to the markets concern.

Also, fluctuations in the demand for agricultural non-food commodities, from rapidly growing emerging economies also contribute to increased volatility.

This volatility also attracts speculators to the commodities markets who hope to benefit from favourable price movements. With the introduction of agricultural commodity derivatives policy, however farmers and other market participants can hedge against these uncertainties by locking in the price of their produce today for delivery at an agreed future date, thus making it easier for them to plan ahead with more ease, and of course with less uncertainly.

This way, continuity in production is ensured, and this helps to attract more farmers into products that are traded via derivatives [47]. Derivatives are instruments whose values are derived from the value of underlying asset, reference rate or index, and they exist as both exchange traded and privately traded contracts.

As with any Exchange, the agricultural derivatives market recognizes the advantage of adding value to those who either participate directly or who refer to the market as benchmark for pricing. For example, the Johannesburg Stock Exchange's Agricultural Products Market is utilized by the cash market in South Africa to determine the fair value of gains [48].

Hence, as derivatives business in the agricultural sector in Nigeria gain traction through the planned resuscitation for the Abuja Commodities Exchange, it is expected that the Exchange will take a cue from the South Africa's largely successful model hinged on transparency and strong regulatory and legal framework.

\section{Section 6 - Conclusion and Way Forward}

Extant literature have shown that investing in agriculture is twice as effective in reducing poverty as investing in other sectors because it offers a pathway to food security, economic well being and social stability for millions of people [49-54].

In Nigeria, where about 60 percent of the working population is employed in agriculture, developing the agricultural sector takes on special significance. But development cannot be imposed from outside; it can only succeed when it is driven by the country itself and implemented by its citizens.

Nigeria's agricultural sector must be seen as a business that works for small and commercial farmers; unlocks the wealth and allows the nation to diversify its income and meet the spiraling food demand of the country's population.

The National Agency for Small Scale Agricultural Development (NASSAD) must endeavour to develop and harmonize its agricultural policies with other agencies active in increasing food production in the country.

The body must strengthen her potential to participate in trade negotiations, meet market access requirements for world trade and build strategic alliances to expand local and foreign direct investments in agriculture. The growth in the agro-allied sector can also be accelerated by increasing the market access through improved rural infrastructure, trade related interventions and by raising the capacities of non-governmental bodies (including commercial and small-holder farmers) to meet the increasingly complex quality and logistic requirements of markets.

There is also the need for the creation of a regulatory and policy framework to facilitate the emergence of regional economic spaces that will spur the expansion of regional trade and cross country investments. There is need for targeted interventions to increase efficiency and profitability along the value-added chains of key agricultural commodities, namely: cotton, cocoa, cassava, oil palm, maize, soya bean, onion, rice, livestock, fisheries, tomato and sorghum.

Though efforts to develop the agro-allied sector has gathered momentum in recent years, especially through increased funding and other measures, it is also important that the government invest sufficiently in agro-related, science and technology based research.

But it is equally important that researchers look beyond the laboratory. Scientists must understand the environment where their discoveries will be used, and the peculiar circumstances of the people who live there.

Equally important, Nigeria should not rely exclusively on research work embarked on in western world as a way to address pertinent issues in its economy.

No one is in a better position than Nigerian themselves to understand the peculiarities in the condition of the Nigerian environment. More research in science and technology will need to be directed towards climate change adaptation and mitigation.

Poor rural people are often the most vulnerable to the effects of climate change. Many live on ecologically fragile land and yet depend solely on agriculture, livestock, fisheries and forestry. Climate change is already having an impact on agriculture in many parts of Nigeria, leading to crop failures, livestock deaths and higher economic losses.

Agricultural research can promote the small holder, the fisherman, the pastoralist, the forest dweller and the herder have the means to adapt to climate change.

Research should ensure that poor rural people, whose lives and livelihoods revolve around the earth's productive capacity, have the means to produce more, and more efficiently too.

Researchers must develop innovative and climate-resilient solutions, such as seeds that are more tolerant to drought or to floods, and make sure they are available to resource poor farmers. In most cases, not the most advanced technology reaps the greatest rewards. 
Sometimes, the best way to grow food is to go back to the basic, building rock dam to stabilize soil and collect water runoff, or constructing cisterns to collect rain water. This is particularly true in dry lands areas, where soils are inherently poor.

Not only does investment in rural development contributes to food security, it can also help stem the flood of immigrants to cities and provide career opportunities for young people in the rural areas. Young people are the life blood of their communities; and when they are forced to leave their homes in search of jobs their villages are left to decay while the constitute a big strain to their destination cities.

But when they can make a good living at home, their energy and creativity can be channeled into reviving their villages. Vibrant rural areas can also ensure a dynamic flow of economic benefits between rural and urban areas so that nations have balanced, deep rooted and sustained development.

Therefore, it is imperative to create robust rural economies that offer attractive opportunities for the young to go back to the land.

\section{References}

[1] N. O. Adedipe, Fluxes, forces and flash flosses in Nigeria agriculture. Abeokuta: University of Agriculture, Alumni Association Lecture Series, 2009.

[2] N. M. Agwu, I. N. Nwachukwu, and B. C. Okoye, "Worsening food crisis in Nigeria: A discourse on bail-out-options," Sacha Journal of Environmental Studies, vol. 1, pp. 64- 68, 2011.

[3] P. A. Okuneye, "Rising cost of food prices and food insecurity in Nigeria and its implication for poverty reduction," CBN Economic E Financial Review, vol. 39, 2001

[4] K. E. Uma, "Population, agriculture, food and poverty in Nigeria: An over view," ABSU Journal of Management Sciences, vol. 3, pp. 23-43, 2007.

[5] African Development Bank Group, "Agriculture and rural institution support project," Appraisal Report for Federal Republic of Nigeria, Tunisia2005.

[6] Central Bank of Nigeria, "Boosting agriculture in Nigeria through agricultural transformation agenda (ATA)," CBN Economic \& Financial Review, vol. 39, pp. 123-134, 2014.

K. Anderson, J. Croser, D. Sandri, and E. Valenzuela, "Agricultural distortion patterns since the 1950's: What needs explaining." Discussion Paper No. 1013.Center for International Economic Studies. Univ. of Adelaide, 2010.

[8] Zenith Economic Quarterly, "Agricultural transformation in Nigeria - Myth or reality," vol. 8, pp. 47-54, 2012.

[9] K. Anderson and W. Masters, Distortions to agricultural incentives in Africa. Washington DC: The International Bank for Reconstruction and Development/The World Bank, 2009.

[10] Agricultural Science and Technology Indicators (ASTI), Retrieved from http: $\backslash \backslash$ www.asti.cgiar.org. [Accessed 2010$], 2010$.

[11] J. Croser and K. Anderson, "Agricultural distortions in Sub-Saharan Africa: Trade and welfare indicators, 1961-2004," 2010.

[12] A. Oyejide. Trade liberalization, regional integration and African development in the context of structural adjustment, chapter 3 in African voice on structural adjustment, International development and research centre Eds., Mkandawire and Soludo. Trenton NJ: African World Press, 2002.

FAOSTAT, Retrieved from http://faostat fao.org, 2011

Comtrade, World integrated trade solutions (WITS), 2010

FAOSTAT, Retrieved from http://faostat.fao.org, 2012.

Idachaba, "Agriculture in Nigeria: Identifying opportunities for increased commercialization and investment, USAID," 2013.

FAOSTAT, Retrieved from http://faostat.fao.org, 2016

FAOSTAT, Retrieved from http://faostat.fao.org, 2015.

African Union, "United Nations office for the special adviser on Africa, new partnership for Africa's development, organization for economic cooperation and development, economic diversification in Africa: A review of selected countries," 2010.

[20] Z. Malley, M. Taeb, and T. Matsumoto, "Agricultural productivity and environmental insecurity in the Usangu plain, Tanzania: Policy implications for sustainability of agriculture," Environment, Development and Sustainability, vol. 11, pp. 175-195, 2009. FAO/UNIDO, "Agricultural mechanization in Africa: Time for action." Retrieved from http://fao-unido.fao.org, 2008.

S. Wolf, "Encouraging innovation for productivity growth in Africa," 2007.

H. Bingswanger-Mkhize, "Challenges and opportunities for African agriculture and food security," presented at the Expert Meeting on how to Food the World in 2050. FAO, 2009.

[24] S. Von Cramon-Taubadel, G. Anriquez, H. De Haen, and O. Nivyevsky, Investment in developing countries' food and agriculture: Assessing agricultural capital stock and their impact on productivity expert meeting on how to feed the world in 2050: Food and Agricultural Organization (FAO), 2009.

[25] F. Ellis and J. Sumberg, "Food production, urban areas and policy reponses," World Development, vol. 26, pp. 213-25, 1998.

[26] J. Maitima, M. Rakotoarisoa, and E. Kangethe, "Horn of Africa: Responding to changing markets in the context of increased competition for resources. Livestock in a Changing Landscape: Experiences and Regional Perspectives," vol. 2, pp. 4-27, 2010.

[27] R. S. Odingo, "Implications for African agriculture of the greenhouse effect in: Soils on a warmer earth," in Proceedings of an International Workshop on Effects of Expected Climate Change on Soil Processes in the Tropics and Subtropics, Nairobi, Kenya, 1990.

[28] B. Sultan and S. Janicot, "Climate and agriculture in West Africa geoconnexion article July 2006." Retrieved from www.geoconnexion.com, 2006.

[29] M. Steinberg, S. Johnson, S. Schierhout, and D. Ndegwa, Hitting home: How households cope with the impact of the HIV/AIDS epidemic. Cape Town: Henry J Kaiser Foundation \& Health Systems Trust, 2002.

[30] FAO/WHO, "Assuring food safety and quality: Guidelines for strengthening national food control systems. FAO Food and Nutrition Paper No. 76." Retrieved from www.fao.org/docrep/006/Y8705E00.htm, 2003.

[31] B. Ndulu and S. O'Connel, The political economy of economic growth in Africa, 2-country case studies: Cambridge University Press, 2008b.

[32] D. Skully, "US tariff rate quotas and AGOA market access international food and agricultural trade policy council (IPC) policy focus Paper July $2010, " 2010$.

P. Collier and J. Gunning, "Why has Africa grown slowly?," Journal of Economic Perspectives, vol. 13, pp. 3-22, 1999.

[34] L. E. Fulginiti, R. Perrin, and B. Yu, "Institutions and agricultural productivity in Sub Saharan Africa " Agricultural Economics, vol. 31, pp. 169-180, 2004.

[35] S. Henson, A. M. Brouder, and W. Mitullah, "Food safety requirements and food exports from developing countries: The case of fish exports from Kenya to the European Union," American Journal of Agricultural Economics, vol. 82, pp. 1159-1169, 2000.

[36] A. Bagumire, E. Todd, C. Muyanja, and G. Nasinyama, "National food safety control systems in Sub-Saharan Africa: Does Uganda's aquaculture control system meet international requirements?," Food Policy, vol. 34, pp. 458-467, 2009.

[37] M. Fafchamps and B. Minten, "Insecurity and welfare: Evidence from County Data," Journal of Development Economics, vol. 45, pp. 831-863, 2009.

[38] Federal Ministry of Agriculture and Water Resources, Agricultural transformation agenda (ATA) - boosting agricultural production in Nigeria. Abuja: Government Press, 2012.

[39] Federal Ministry of Agriculture \& Rural Development, Building on the gains of agricultural transformation agenda and making agriculture a viable business in Nigeria. Abuja: Government Press, 2015.

[40] A. Abdulai, C. Barrett, and J. Hoddinot, "Does food aid really have disincentive effects? New evidence from Sub-Saharan Africa," World Development, vol. 33, pp. 1689-1704, 2005. 
[41] Central Bank of Nigeria, "Boosting agricultural production in Nigeria," CBN Economic and Financial Review, vol. 39, pp. 79-93, 2010.

[42] S. Khan, M. A. Hanjra, and J. Mu, "Water management and crop production for food security in China: A review," Elsevier: Agricultural Water Management, vol. 96, pp. 349-360, 2009.

[43] X. Diao, S. Fan, D. Headey, M. Johnson, A. NinPratt, and B. Yu, "Accelerating Africa's food production in response to rising food prices: Impacts and requisite actions, Discussion Paper No. 825. International Food Policy Research Institute," 2008.

[44] National Emergencies Management Agency (NEMA), "Averting food crisis in the North East Nigeria," NEMA Quarterly Report, Abuja: Government Press2014.

[45] E. E. E. Eyo, "Implication of pricing for national food security, CBN Bullion," vol. $21,1997$.

[46] A. Fosu, "Effect of export instability on economic growth in Africa," Journal of Developing Areas, vol. 26, pp. 323-332, 1992.

[47] S. Haggblade and P. Hazell, Successes in African agriculture: Lessons for the future. Washington DC: Johns Hopkins University Press, 2010.

[48] C. Barrett and E. Mutambatsere, Agricultural commodity markets in developing countries. In: S.N. Durlauf and L.E. Blume, Editors, The new Palgrave dictionary of economics, 2nd ed.: Palgrave Macmillan, 2008 a.

[49] H. Burton, Import substitution. In handbook of development economics vol. 2. Chenery, Srinivasan: Elsevier Science Publishers, 1989.

[50] C. Delgado, M. Rosegrant, H. Steinfeld, S. Ehui, and C. Courbois, "Livestock to 2020: The next food revolution. Food ag riculture and environment," Discussion Paper No. 28. International Food Policy Research Institute, 1999.

[51] Food and Agriculture Organization (FAO), Growing demand on agriculture and rising prices of commodities, an opportunity for smallholders in low agricultural-based countries? Rome: FAO, 2008.

[52] P. Collier, W. Gunning, S. O'Connell, and B. Ndulu, "Harnessing growth opportunities: How Africa can advance. The political economy of economic growth in Africa, 1960-200: In the political economy of economic growth in Africa, 1960-200. 1. Eds," 2009.

[53] Food and Agriculture Organization of the United Nations (FAO), "The state of food insecurity in the world: Addressing food insecurity in protracted crises," 2010.

[54] C. Donovan, R. Myers, D. Tschirley, and M. Weber, "The effects of food aid on maize prices in Mozambique. In G. H. Peters and von Braun (Eds), Food security, diversification and resource management: Refocusing the role of agriculture," in Proceedings of the 23rd International Conference of Agricultural Economists, 1999.

Citation | Onwuka, Ifeanyi Onuka (2017). Reversing Nigeria's Food Import Dependency - Agricultural Transformation. Agricultural Development, 2: 1-12.

\section{History:}

Received: 14 March 2016

Revised: 21 April 2016

Accepted: 24 April 2016

Published: 27 October 2016

Licensed: This work is licensed under a Creative Commons

Attribution 3.0 License (cc)

Publisher: Eastern Centre of Science and Education
Funding: This study received no specific financial support.

Competing Interests: The author declares that there are no conflicts of interests regarding the publication of this paper.

Transparency: The author confirms that the manuscript is an honest, accurate, and transparent account of the study was reported; that no vital features of the study have been omitted; and that any discrepancies from the features of the study have been omitted
study as planned have been explained.

Ethical: This study follows all ethical practices during writing.

Eastern Centre of Science and Education is not responsible or answerable for any loss, damage or liability, etc. caused in relation to/arising out of the use of the content. Any queries should be directed to the corresponding author of the article. 